\title{
BLOOD-SUCKING MIDGES FROM THE GENUS Culicoides (Diptera: Ceratopogonidae) ACT AS FILED VECTORS OF HUMAN AND ANIMAL DISEASES \\ (review)
}

\section{A.V. SPRYGIN1, O.A. FEDOROVA², YU.YU. BABIN¹, A.V. KONONOV1, A.K. KARAULOV 1}

${ }^{1}$ Federal Centre for Animal Health, mkr. Yur'evets, Vladimir, 600901 Russia, e-mail sprygin@arriah.ru;

2All-Russian Research Institute of Veterinary Entomology and Arachnology, 2, ul. Institutskaya, Tyumen, Tyumen Province, 625041 Russia, e-mail fiodorova-olia@mail.ru

Received August 19, 2014

\section{Abstract}

Bluetongue and Shmallenberg diseases, the arboviral infections of ruminants, caused by Bluetongue virus (BTV) of Orbivirus genus (Reoviridae) and so-called Shmallenberg virus (SBV) preliminarily attributed as a member of Orthobunyavirus genus (Bunyaviridae), respectively, are mainly transmitted by blood-sucking midges from Culicoides genus. They are widely distributed, with a total of over 80 species documented in Russia (V.M. Glukhova, 1989), including the Far North territories. Of them, a total of 68 species are associated with Siberia and the Far East. They are C. obsoletus, C. okumansis, C. scoticus, C. pulicaris, C. grisescens, C. pallidicornis, C. sufascipennis, C. fascipennis, C. cubitalis, C. stigma, C. helveticus, C. parroti, C. vexans, C. custans, C. letifrontis, C. nubeculosus, C. circumscriptus, C. salinarius, C. pectipennis, C. odibilis, C. simulator, C. ibericus, C. sinanoensis, C. sanguisuga, C. filicinus, C. chiopterus, C. fagineus, C. riethi, C. gornostaevae, C. punctatus, C. impunctatus, C. reconditus, C. pallidicornis, C. manchuriensis, C. dobyi, etc. Numerous small ponds, marshy areas and litter from decaying plant remains in different landscape and climatic zones are favorable for the development of insects. The unprecedented incursions of BTV (six serotypes in 12 EU countries since 1998 (B.V. Purse et al., 2005), and the emerging so-called Schmallenberg virus (B. Hoffman et al., 2012) underscored a need to revise the list of Culicoides species, following climate change events. Only a few recent studies have been reported so far, which negatively affects risk analysis and impedes understanding the biology of vector-borne diseases. This review attempts to briefly describe Culicoides species in Russia and consider their role in the context of vector-virus-host. Characteristics of Culicoides populations at different habitats are discussed. The endogenic mechanisms of interaction between the vectors and the transmitted viruses are considered in more detail. A probability of BTV permission in livestock in Russia is considered based on overwintering and transmission mechanisms.

Keywords: midges, Culicoides, vectors, biodiversity, arboviral infections, bluetongue, Shmallenberg disease.

Biting midges (Ceratopogonidae) are the smallest $(1-4 \mathrm{~mm})$ bloodsucking two-winged flies of the blood-sucking insect complex which also includes horse flies (Tabanidae), mosquitoes (Culicidae), black flies (Simuliidae) and gnats (Phlebotomidae). Most of biting midge species are distinguished by wing patterns, particularly several dark spots against a light background or vice versa. They are mainly represented by only one genus Culicoides, the species of which are referred to blood-sucking insects. There are more than 1,000 biting midge species in the world fauna, including 130 species in the former USSR territory, more than 80 species in Russia [1] and 68 species in Siberia and the Far East [2].

In the Cis-Ural region (Kama Region of Perm Territory), where studies were carried out since 1960-1969, several species of the genus Culicoides and one species of the genus Forcipomium were revealed in seven administrative districts: C. obsoletus, C. okumansis, C. scoticus, C. pulicaris, C. grisescens, C. pal- 
lidicornis, C. subfascipennis, C. fascipennis, C. cubitalis, C. stigma, C. helveticus, $C$. parroti, $C$. vexans, $C$. custans, $C$. letifrontis, $C$. nubeculosus, $C$. circumscriptus, C. salinarius, C. pectipennis, C. odibilis, C. simulator, C. ibericus, Culicoides sp. nov., Forcipomyia (Lasiohelea) sibirica [3]. A dominant species among them was $C$. obsoletus followed by $C$. pallidicornis. Biting midges are found everywhere in the Cis-Ural region. Numerous water bodies and damp forest litter with decaying plant residues favor the development of these insects. The flight of adult insects lasts 4.0-5.5 months (from May to October) with two population peaks (in the second half of June and in mid-August).

In Krasnoyarsk Territory, biting midges are represented by 14 species: C. sinanoensis, $C$. sanguisuga, $C$. filicinus, $C$. chiopterus, $C$. pulicaris, $C$. fagineus, C. grisescens, C. odibilis, C. subfascipennis, Culicoides sp. nov. (gr. minutissimus), C. riethi, C. stigma, C. helveticus, Forcipomium sibirica [4]. In the southern part of Tyumen Region, 17 species are found: $C$. obsoletus, $C$. chiopterus, C. gornostaevae, C. pulicaris, C. punctatus, C. impunctatus, C. grisescens, C. reconditus, C. fascipennis, C. subfascipennis, C. pallidicornis, C. circumscriptus, C. salinarius, C. manchuriensis, C. nubeculosus, C.stigma, and C. helveticus, the species $C$. punctatus being the most numerous among them [5].

A total of 34 species have been identified in the southern taiga subzone of Tomsk Region, and the most common ones among them were $C$.grisescens, C. pulicaris, C. obsoletus and C. chiopterus. 17 species have been described in the forest-steppe zone of Novosibirsk Region: $C$. obsoletus, $C$. chiopterus, $C$. pulicaris, C. punctatus, C. grisescens, C. reconditus, C. fascipennis, C. pallidicornis, $C$. stepicola, $C$. vexans, $C$. variifrons, $C$. circumscriptus, $C$. salinarius, C. sphagnumensis, $C$. manchuriensis, $C$. nubeculosus, $C$. riethi $[2,6,7]$. The most numerous species at breeding places were $C$. riethi, $C$. circumscriptus and C. salinarius.

Western Siberia is rich in the river system, which creates favorable conditions for insect reproduction.

The publication of 1969 on the fauna of biting midges in the northern areas of Siberia in the forest tundra zone describes 11 species: C. obsoletus, C. pulicaris, C. impunctatus, C. fascipennis, C. sensillatus, C. circumscriptus, C. salinarius, $C$. manchuriensis, $C$. sibiricus, $C$. riethi, $C$. helveticus. The most numerous species were $C$. circumscriptus, $C$. riethi, $C$. salinarius, the other species were found in small numbers [6]. The undertaken studies have demonstrated that the survey areas are different from each other in climatic and landscape features. For example, in the Far North areas, almost all area of Magadan Region is located in the permafrost zone. The studies of the fauna and ecology of biting midges in Magadan Region in 1966-1969 resulted in registration of seven species. i.e. C. stigma, C. helveticus, C. pulicaris, C. grisescens, $C$. obsoletus, $C$. okumensis, $C$. fascipennis, the dominant species being $C$. pulicaris [7]. Its predominance over all the other species is typical for areas with harsh climate $[6,8]$. The biting midge flight begins in the first decade of July and lasts 2.5 months on average. The number of biting midges is not large.

On the Taimyr Peninsula, biting midges are few in numbers and registered occasionally, therefore, they are considered as insignificant representatives of blood-sucking insects. Their distribution depends on abiotic factors [8]. Thus, they are not observed in mountain tundra and mountain taiga. In plain tundra, they are found in hot and early summer (in 1967, they were registered occasionally in the first half of July only) and are absent in colder seasons. In forest tundra, biting midges are observed not every year, but only in the warmest years [8]. 
Studies in the Sakha Republic (the former Yakut Autonomous Soviet Socialist Republic) resulted in the identification of 11 biting midge species. Two of them, $C$. pulicaris and $C$. fascipennis, were dominant, whereas $C$. grisescens, C. obsoletus, C. actoni (okumensis), C. stigma, C. helveticus, C. simulator, $C$. subfascipennis, $C$. circumscriptus and $C$. manchuriensis were few in numbers $[9,10]$. The biting midge flight period lasts 1.5 months. The first biting midges appear in decade II of July, and intensive flight is observed in August.

In 1967, surveys in the north-east part of Siberia (the settlement of Markovo, Chukotka Autonomous District) resulted in the identification of six biting midge species. One of them (C. pulicaris) was dominant, while the other (C. grisescens, C. obsoletus, C. fascipennis, C. okumansis, C. stigma) were few in numbers [6].

Summarizing the published data which reflect the previous studies of biting midges in the northern areas of Siberia, the following conclusions can be drawn. The Far North is still understudied in this regard. The species composition of biting midges more closely depends on the latitude than their number. The latter is subject to significant variations under the influence of regional climatic conditions and hydrological regime.

In the publication of 1987, A.G. Mirzaeva [11] modifies the distribution limits of biting midge dominant species in Siberia and the Far East. It is reported about biting midges of six subgenera. The species of the subgenus Avaritia found in Western Siberia (in particular, in the southern taiga of the Cis-Ob region) are C. dobyi, C. obsoletus, C. gornostaevae, C. sinanoensis and C. chiopterus. $C$. okumensis $(=C$. actoni) is denoted as a representative of the fauna of the Far East and Altai. Having analyzed the publication, we can draw a conclusion about distribution and interlandscape confinedness of species (this refers to the habitat of such common species as C. grisescens, $C$. obsoletus and $C$. okumensis).

The species composition and distribution of biting midges in Siberia and in the Urals are understudied, and the available data are rather scarce. This can be explained by the difficulties associated with the investigation of these insects, their small size and dispersion of breeding places.

As for the European part of Russia, the presented data on biting midges of the genus Culicoides are fragmentary and refer to individual regions only. Thus, in the Komi Republic, such faunistic researches of biting midges were carried out in 1969 [12] in the forest tundra and taiga zone. The researchers used such basic accounting methods as insect collection from themselves and animals. 19 biting midge species of the genus Culicoides were found in the Komi Republic: C. pulicaris, C. grisescens, C. fagineus, C. impunctatus, C. obsoletus, C. chiopterus, $C$. stigma, $C$. helveticus, $C$. fascipennis, $C$. subfascipennis, $C$. pallidicornis, C. cubitalis, C. cunctans, $C$. carjalaensis, C. circumscriptus, C. salinarius, $C$. machardyi, $C$. simulator, $C$. odibilis [12]. The most common species were C. pulicaris (especially C. pulicaris pulicaris), C. grisescens, the obsoletus and fascipennis groups.

The authors noted that the flight of biting midges in taiga begins in decade I of June, lasts till snow falling (early or late October) and consists of two peaks. C. obsoletus, $C$. chiopterus, $C$. stigma, $C$. fascipennis fly out and attack first (spring and early-summer species). C. pulicaris, $C$. subfascipennis, $C$. impunctatus, $C$. pallidicornis and occasionally $C$. grisescens appear at the beginning of July. The massive attacks of the last species were observed at the end of July. The first population peak coincides with the end of June and is associated with the development of biting midges from the obsoletus group, while the second one (much greater than the first one) is observed in decades II and III of $\mathrm{Au}$ - 
gust and is due to $C$. pulicaris. In September, the number of bloodsuckers decreases, however, attacks are noted till mid-October. The dominant species in autumn are $C$. pulicaris, $C$. grisescens and, in some years, the obsoletus group.

In forest tundra, the maximum number of biting midges was observed in decade III of July at polar twilight. As in taiga, attacks in this period may be of the first or second type, depending on night temperatures. The first type of diurnal rhythm is characterized by the large number of attacks in the evening, all night and in the morning. In the daytime, attacks cease due suppressive action of strong light. This type is possible when temperature during night holds in the optimum range. The diurnal rhythm may be different in the same period. In the second type of diurnal rhythm, the day suppression is followed by the evening maximum, however, temperature drop by night causes the flight to stop (although night light is optimal). Then, the flight recommences with the temperature rise and turns into the morning maximum. The further increase in light intensity and temperature rise leads to the absence of attacks in the daytime. In the seasons with dark nights, two diurnal rhythm types are possible, depending on the combination of illuminance and temperature. A substantial difference of the insect diurnal rhythm in forest tundra from that in taiga consists in quite high attack rate in the daytime. In August, nights become dark, which leads to no attacks even at optimal temperatures. The diurnal rhythm consists of the morning maximum, moderate day activity, evening maximum and absence of night attacks.

High light tolerance of biting midges was noted in the Komi Republic [12], unlike previous data on Karelia [13, 14] and Primorsky Territory [15]. The high light tolerance of these insects in forest tundra is probably explained by short summer with almost 24-hour light.

Thus, forest tundra is characterized by greater ecological plasticity of biting midges as compared to taiga, which is connected with specific conditions of the north. Breeding places include muddy streams, damp and muddy depressions at the edges of swamps and roads, i.e. various water reservoirs and wet, swampy soil. As compared to forest tundra, conditions for biting midge breeding and imago existence in the taiga zone are more favorable because the forest cover reduces surface runoff and evaporation. Also, there are no large open spaces, which contribute to attack activity and increase in number of biting midges.

In forest tundra and taiga, we may note the predominance of $C$. pulicaris, a species with high ecological plasticity (about $90 \%$ and up to $67 \%$ of biting midges in forest tundra and taiga, respectively). The species $C$. fascipennis and C. chiopterus are in the second place with regard to number (1.5-1.8 \%) in forest tundra. Probably, $C$. obsoletus and $C$. grisescens are typical for forest landscape, which is also indicated by other authors $[14,16]$.

In Voronezh, in the southern part of European Russia, faunistic collection took place from 1954 to 1963 [17]. A total of 20 biting midge species were identified during the studies. The dominant species in the conditions of Voronezh Region were $C$. pulicaris, $C$. obsoletus, C. simulator, C. fascopennis, C. pallidicornis and C. subfascipennis, whereas $C$. nubeculosus, C. riethi, C. pictipennis, $C$. odibilis, $C$. tentorius and $C$. vexans are less numerous. In contrast with these species, $C$. stigma, $C$. circumscriptus, $C$. salinanus, $C$. impunctatus, $C$. grisescens, $C$. chiopterus, $C$. cubitalis and $C$. truncorum biting midges are found rarely and in small numbers. $C$. fascipennis, $C$. subfascipennis and $C$. vexans biting midges exhibit the variability of some morphological characters. The presence of $C$. nubecutosis, $C$. riethi, $C$. stigma, $C$. circumscriptus, $C$. pulicaris, C. impunctatus, C. grisescens, C. obsoletus, C. pictipennis, C. simu- 
lator, C. fascipennis, C. pallidicornis, C. subfascipennis and $C$. vexans in the surveyed territory is typical, because they, as far as it is reported, are noted both to the north and south of Voronezh Region. C. circumscriptus, C. salinarius, $C$. grisescens, $C$. impunctatus and $C$. cubitalis, $C$. truncorum are few in numbers and rare in these conditions. A total of 17 species of the identified fauna bite humans and animals, and no attacks were noted only for three species (C. salinarius, $C$. odibilis and $C$. truncorum).

It was established that, under the conditions of the Voronezh Region, the flight of biting midges lasts from decade II of May till decade II of October (within 4.5 months), and the most numerous species are C. pulicaris, C. obsoletus, C. simulator, C. fascipennis, C. pallidicornis and C. subfascipennis.

Analyzing the specialist literature and our data on the influence of temperature and illuminance on biting midge activity in different regions of the USSR, we may note the plasticity of this group of insects, and regular variations in biting midge behavior are observed with regard to these factors (temperature and light) when moving from the north to the south. Thus, the lower temperature limit for biting midges is $+4.0{ }^{\circ} \mathrm{C}$ in Karelia, $+4.8{ }^{\circ} \mathrm{C}$ in Tomsk Region, $+5.0 \ldots+6.0^{\circ} \mathrm{C}$ in Primorsky Territory, $+8.3^{\circ} \mathrm{C}$ in Moscow and Ryazan Regions, $+8{ }^{\circ} \mathrm{C}$ in Voronezh Region, $+9{ }^{\circ} \mathrm{C}$ in Transcaucasia. The temperature zone of cold suppression expands from the north to the south. The behavior of biting midges toward the light also changes, and they adapt to higher illuminance values when moving to the south. Thus, the maximum number of attacking midges was noted at 51-100 lx in Primorsky Territory, 101-1,000 lx in Voronezh Region and 200-2,000 lx in Transcaucasia [17].

Breeding places for 15 biting midge species were identified in Voronezh Region. These are springfed water bodies, intermittent water bodies formed as a result of ice melting or filled with flood and rain water, micro water bodies (pools, ditches), swampy paths in forests, wet soil of forest pastures, swamped locations near moss lands, near-root hollows in tree trunks, old rotten stumps, as well as the littoral zone of rivers with muddy banks.

With regard to the Northwestern Federal District, the biting midge fauna was studied in Leningrad Region [14, 18, 19], including preimaginal phases (20), as well as in Pskov Region [21, 22].

A total of 113 biting midge species belonging to 17 genera of the family Ceratopogonidae were identified in Leningrad Region. Among bloodsuckers of the genus Culicoides, the dominant species here were C. punctatus, C. obsoletus, $C$. grisescens and $C$. fascipennis. $C$. impunctatus and $C$. pallidicornis can also be referred to numerous species (they were predominant in some areas). It was shown that $C$. obsoletus and $C$. chiopterus (subgenus Avaritia) are widespread and confined to the forest zone. They are most numerous in the north of the forest zone of Russia.

A totsl of 15 biting midge species were identified in Pskov Region [21]. They are C. obsoletus, C. pallidicornis, $C$. punctatus, $C$. grisescens, C. chiopterus, $C$. impunctatus, $C$. fascipennis, $C$. pulicaris, $C$. nubeculosus, $C$. riethi, C. stigma, C. scoticus, C. salinarius, C. odibilis, C. segnis. The first eight of them were found in collections from the cow. It is important to note that general pattern of the seasonal variations of biting midge number is determined by four dominant species, the $C$. obsoletus, $C$. pallidicornis, $C$. punctatus and C. grisescens. At that, 97.9-100\% of insects collected from the cow belonged to these species, while the other species were few in numbers, and only occasional individuals attacked the cow.

The subzone of mixed forests, including Pskov Region, is characterized by the bimodal type of the seasonal variation of biting midge number and 
by the total flight period duration equal to 5.0-5.5 months, from May to October [18, 23-25].

In another study with collection on human baits, six biting midge species (C. fascipennis, C. impunctatus, C. helveticus, C. obsoletus, C. punctatus and $C$. reconditus) were identified in Leningrad Region and adjacent territories. Authors described all of them as typical for the listed territories, however, C. punctatus was not indicated for Estonia, but was previously noted in Leningrad Region [22] and in the south of Finland [26]. At the same time, the authors of the cited source did not find 29 biting midge species indicated in literature for Leningrad Region, Estonia and southern Finland (due to landscape features and method used, i.e. collection on human).

It is reported $[3,22]$ that the fauna of biting midges in Leningrad Region amounts to 36 species of the genus Culicoides. It was noted that the fauna of the territory adjacent to the Gulf of Finland is represented by 80 species of bloodsucking two-winged flies, including 35 mosquito species, 22 black fly species, 6 biting midge species of the genus Culicoides and 17 horse fly species. C. helveticus was noted in spruce forest to the south the Gulf of Finland; it was not described on the peninsula in other biotopes.

The study of the biting midge fauna in the Nonchernozem Zone of Russia revealed the following species: C. obsoletus, C. pulicaris, C. stigma, C. nubeculosus, C. chiopterus and $C$. punctatus [27-29]. In Ivanovo Region, the dominant species $C$. obsoletus and $C$. chiopterus [30] were caught on sheep, and $C$. obsoletus, C. pulicaris, C. stigma, C. nubeculosus, C. chiopterus and C. punctatus were registered as potential bluetongue disease transmitters on cattle [27-30]. All of them are polyvoltine species; they attack hosts from May to October and have at least two generations per season, and females are able to repeat gonotrophic cycles throughout their life [30].

It should be noted that Ivanovo Region is one of the most dipterologically studied areas in the central part of the Nonchernozem Zone of Russia: the complex of blood-sucking two-winged insects has been investigated here for over 70 years. For the adjacent regions, for example, Vladimir and Nizhny Novgorod (former Gorky) Regions, literature contains only isolated reports about the fauna of genus Culicoides biting midges as of 1950-1960 [31, 32], and no information is available for Yaroslavl and Kostroma Regions.

A total of 26 biting midge species of the genus Culicoides have been registered in the fauna of Ivanovo Region over the last about 50 years. Their species composition is referred to the complex which is typical for mixed forests [16, 33, 34].

As reported by V.A. Isaev [27-30], biting midges are prone not only to zoophilia, but also to anthropophilia expressed in various degrees. The representatives of $C$. punctatus are the most noticeable insects in the structure of the species attacking cattle, horses and humans. The share of $C$. nubeculosus of on cattle and horses was not large, and it was not found on sheep (of the three species, only $C$. obsoletus was collected on sheep, just like in case of all other types of hosts).

In order to identify transmitter biting midges, it is important to know information about the temperature range where attacks are possible, as well as optimal attack temperatures. In case of populations in the Nonchernozem Zone, they are equal to $15^{\circ} \mathrm{C}\left(3-24^{\circ} \mathrm{C}\right)$ for $C$. punctatus, $17^{\circ} \mathrm{C}\left(10-23^{\circ} \mathrm{C}\right)$ for $C$. obsoletus and $19{ }^{\circ} \mathrm{C}\left(13-27^{\circ} \mathrm{C}\right)$ for $C$. nubeculosus [33]. At the same time, to the north, these indices, for example, for $C$. obsoletus are lower [1], which may favor disease transmission. 
V.A. Isaev [34] believes that the environmental specificity of biting midges shall also be analyzed with regard to transition from the continuous development within the season to the establishment of life cycles with different diapause forms. Thus, in Nigeria, where Shamonda virus was first isolated, the tropical species of Culicoides develop continuously throughout the year [35].

In Western Asia (in Israel), the key transmitter of bluetongue disease, C. imicola, develops all year round [36]. However, in Russia and the neighboring republics of the former USSR, no year-round imago flight was noted for any of 130 Culicoides species known for these territories, even in the far south [1]. According to data from V.A. Isaev [28], diapause (its characteristics and governing factors, in particular, temperature) defines the specific features of Culicoides biology and ecology in a particular region.

The environmental specificity of potential vectors can be traced in the analysis of biting midge ecology in respect to imago and preimaginal stages. The larvae of key transmitters of bluetongue and similar diseases generally develop in excrements of ruminants. Such facts were noted, for example, for $C$. imicola, C. variipennis, C. brevitarsis and closely related species [37].

A total of 17 biting midge species were found in the northern part of European Russia (the Republic of Karelia): C. obsoletus, C. chiopterus, C. grisescens, $C$. pulicaris, $C$. impunctatus, $C$. fagineus, $C$. fascipennis, $C$. subfascipennis, C. pallidicornis, C. albicans, C. punctans, C. stigma, C. circumscriptus, $C$. salinarius, $C$. carjalaensis, $C$. odibilis, $C$. pictipennis $[1,13,14,20]$.

In the conditions of the southern and middle areas of Karelia, the biting midge flight period lasts from late May-early June till late Septemberfirst half of October, i.e. 4.0-4.5 months. Two population maximums are observed during this period, the first in the second half of June-first half of July, and the second from late July till early September. Such flight duration and the presence of two maximums are explained by the emergence of dominant species at different times.

The seasonal dynamics of biting midge population number is different in the northern areas of the republic and on the Kola Peninsula. The flight period in the Khibiny is shorter and begins later [39]. The first biting midge specimens were found on July 18, and a flight maximum was observed in August.

To the south of Karelia, in Estonia [18, 19] and Moscow and Ivanovo Regions [40], the biting midge flight period somewhat extends and lasts from mid-May till the end of October. Most of biting midge species in Karelia hibernate in the larval stage. One of the species (C. grisescens) hibernates in the egg stage, which explains its late emergence and population maximum in the second half of summer.

The number of generations for most of biting midge species in Karelia is one per year, except for $C$. pulicaris and $C$. stigma having two generations. For most of the species in Moscow, Ryazan and Ivanovo Regions, two generations are noted, whereas $C$. pulicaris has at least three generations [23, 24, 40]. It was demonstrated that $C$. grisescens is confined to unpopulated or scarcely populated forest areas. At the same time, $C$. pulicaris and $C$. fascipennis constitute the significant part of entomofauna both in the scarcely populated areas of Karelia and in the populated areas of Moscow and Ivanovo Regions [40].

In studying the biting midge species diversity in Dagestan in 1966-1968 [41], it was shown that they are one of the key components of the bloodsucking insect complex there Midges were caught on humans and horses. A total of 10 species of the genus Culicoides (C. nubeculiosus, C. puncticollis, C. riethi, C. parotti, C. circumscriptus, C. pulicaris, C. obsoletus, C. marritimus, $C$. simulator, $C$. bulbostulus) and one species of the genus Leptoconops 
(L. mediterraneous) were identified. It is important to note that $C$. maritimus, $C$. simulator, $C$. bulbostulus and $L$. mediterraneus turned out to be new for all North Caucasus. However, based on the results of earlier studies which were first carried out in Dagestan in 1967 [42], only three species and one subspecies of the genus Culicoides ( $C$. puncticollis, $C$. pictipennis, $C$. subfascipennis, $C$. pulicaris punctatus) and one species of the genus Leptoconops (L. bodentatus) were found.

The first biting midges in Dagestan begin to attack at daily average air temperature within $9-11{ }^{\circ} \mathrm{C}$. In the semidesert zone, due to early spring, they emerge in April and attack till October. The mass flight was noted from late April till late May. Then the number gradually decreases due to dryout of breeding places. The biting midge species composition also changes. While six species (C. nubeculosus, C. riethi, C. pulicaris, C. maritimus, C. simulator and L. mediterraneus) were identified in May, only $C$. pulicaris attacks in July [41].

Thus, the literature review suggests that biting midges are distributed almost everywhere in different landscape climatic and geographical zones of the Russian Federation, except for typical tundra [43]. In the Far North areas, biting midges are the most scarce and insignificant representatives of blood-sucking insects [8].

At present, biting midge preimaginal stage development places are classified as proposed by V.M. Glukhova (1989) [1] who divided all breeding places into two basic groups: aqueous and ground. The ground medium includes rotting wood and bark, as well as decaying organic substrates of animal and plant origin. The aqueous medium consists of strictly aqueous and semi-aqueous medium subgroups. The strictly aqueous medium includes perennial water bodies, such as lakes, ponds, rivers, streams, thermal water bodies and mineral water sources, and the semi-aqueous one includes intermittent water bodies, swamps and swampy meadows.

The methods for studying the biology and ecology of biting midges are described in details in a number of papers [1, 18, 21, 44, 45].

It is important to note that biting midges are wide-spread not only in all landscape and geographical zones of Russia, but also all over the world, except for New Zealand (Arbovirus Surveillance Program of New Zealand, 2013). The harm caused by biting midges is that these insects transmit pathogens of some infectious and invasive diseases of humans and animals. At present, in connection with agricultural development and purchasing of highly-productive pedigree livestock, it is possible that exotic transmissible infections, such as Schmallenberg and bluetongue diseases, will be brought into Russia.

The key transmitters of bluetongue virus (BTV) are the representatives of C. imicola in Africa, the Middle East and Southern Europe, C. sonorensis in North America and C. brevitarsis in Australia. Bluetongue virus vectors in Europe are biting midges from the obsoletus and pulicaris complexes [47]. The vectors for the pathogen of another arbovirus infection, Schmallenberg disease, are $C$. dewulfi, C. scoticus, C. obsoletus sensu stricto and C. chiopterus [48-50].

According to the presented data, there are the following dominant species of biting midges in the territory of Russia: C. obsoletus, C. pulicaris, $C$. punctatus and $C$. chiopterus [1]. However, their competence as the vectors of the bluetongue and Schmallenberg disease pathogens under the conditions of Russia is still understudied.

As noted above, biting midges of the genus Culicoides are spread throughout the territory of Russia, and their northernmost habitat includes the Republics of Karelia, Komi and Sakha, as well as Magadan and Chukotka. The northernmost species is C. pulicaris in Magadan [7], Chukotka [8], Sakha Re- 
public [9-11] and Komi Republic [51], and its predominance is typical for areas with harsh climate $[6,8]$. On the Taimyr Peninsula, biting midges are few in numbers and registered occasionally; in mountain taiga, they are absent at all [8]. The dominant species in taiga areas, such as Karelia, are C. impunctatus, $C$. obsoletus and $C$. grisescens. Numerous water bodies, pools, swamped areas, as well as damp forest litter with decaying plant residues, favor the development of these insects [1].

Biting midges are found in all landscape and geographical zones of Russia, except for typical tundra [8, 43], but they are most numerous in the forest zone, where their flight is observed within 4.0-4.5 months: from late May-early June till late September-early October. Two mass flight periods are recorded during the season in most of the regions of Russia: the first-from mid-June till mid-July and the second-in August. The second rise of population is mainly caused by the $2^{\text {nd }}$ generation of some species which were dominant in the $1^{\text {st }}$ generation, as well as late-summer species. Biting midges are crepuscular insects, and two maximums are observed in their diurnal rhythm of activity: during sunrise and sunset hours. They do not attack during the day-time in sunny weather. Activity decrease is observed in the night-time, but great numbers of insects also attack their victims during the night in the mass flight period. Biting midges are active at temperature within $5-30^{\circ} \mathrm{C}$ and illuminance from 0 to $40,000 \mathrm{~lx}$. They primarily hibernates as larvae at stages III-IV. These insects attack humans and animals in the wide range of air temperature (from 5 to $30^{\circ} \mathrm{C}$ ) and illuminance (from 0 to $40,000 \mathrm{~lx}$ ), but optimal temperature and illuminance are $7-22{ }^{\circ} \mathrm{C}$ and 100-5,000 lx, respectively. Relative humidity within 40-90\% does not influence the activity of biting midges. The biting midges of the obsoletus and pulicaris complexes, as a rule, have two generations in central Russia [27-30, 33, 34], one generation in the north of the Russian Federation $[8,11,12]$ and three generations in Northern Europe [52].

As in case of other blood-sucking insects, only female biting midges suck blood. They need blood for egg maturation. All of them are characterized by socalled gonotrophic harmony when blood digestion occurs simultaneously with egg maturation. Throughout the life, a female can lay eggs 1-3 times, but only after it sucks blood. Basic food for males and females is nectar, as well as other plant secretions and saps. Thus, only females are linked with animals during blood sucking. Female biting midges attack humans and animals both outdoors and indoors (they actively fly into rooms). Different biting midge species of the genus Culicoides exhibit both exophagy and endophagy [53].

After a midge bites a viremic animal, the virus in the vector organism replicates in intestine cells and then enters hemocoel and salivary glands where it reproduces itself in cells [47]. However, not all species can be efficient vectors of infection. Thus, full dissemination of virus in the insect organism is possible for only 50 of 1,500 known Culicoides species (due to existing natural endogenic barriers) [54-56].

It is important to note that biting midge salivary gland enzymes are able to break up the core protein of viruses with formation of so-called infectious subviral particles which exhibit increased infection activity [57]. This fact emphasizes the role of certain species of the genus Culicoides as efficient vectors because the enzyme composition of saliva may vary and have a significant influence on virus dissemination within the insect organism [57].

The time interval between virus penetration into intestine cells and entry into salivary glands is known as an extrinsic incubation period; its duration substantially varies depending on ambient temperature and vector population [18]. Thus, low $(0.4 \%)$ sensitivity to experimental introduction of bluetongue virus 
infection in $C$. impunctatus is shown, whereas this parameter for $C$. obsolutes is within 0.4-7.4\% [58]. At low temperature $\left(<10^{\circ} \mathrm{C}\right)$, bluetongue virus may persist in the adult insect organism (imago) up to 35 days, and replication resumes under favorable conditions and at higher temperatures [59]. The competence of the insects which are usually not vectors (for example, C. nubeculosus) may be induced if larvae grow at $33-35^{\circ} \mathrm{C}$, whereas the adult biting midges raised at $30{ }^{\circ} \mathrm{C}$ are insusceptible to infection [59, 60]. In addition, high temperature favors the rapid development $\left(6-8\right.$ days at $25^{\circ} \mathrm{C}$, and 4 days at $\left.30^{\circ} \mathrm{C}\right)$ and survival of larvae $[59,60]$.

For Shmallenberg virus (SBV), prevalence in vectors from the obsoletus complex was $0.5 \%$ of total number of caught insects, which is 5 times higher than for bluetongue virus of serotype 8 (BTV-8) in biting midges from the obsoletus complex in 2006-2010 in case of natural contamination [24]. Similar prevalence was shown for Akabane virus in C. brevitarsis in Australia [61-64]. Therefore, the sensitivity of transmitters to infection contamination turns out to be much lower in natural conditions, which shall be taken into account in analyzing the epizootological situation. However, in another study, the prevalence of Shmallenberg virus in biting midges in the south of Belgium was $2.86 \%$ of the total insect number [6].

Thus, studying biology of this vector opens still newer aspects of interaction in the virus-vector-host system, which can significantly change current scientific ideas regarding the transmission and epizootiology of arbovirus infections.

The unprecedented spread of six serotypes of bluetongue virus in Europe in 12 EU countries since 1998 [47], as well as previously unknown Shmallenberg virus [65], has forced us to take a fresh look at the epizootiology of the arbovirus infections transmitted by biting midges of the genus Culicoides in connection with climate warming. Therefore, now it is not reasonable to strictly adhere to the endemic area of bluetongue in the zone within $40-50^{\circ} \mathrm{N}$ and $35^{\circ} \mathrm{S}$ [66].

The interrelationship between the population dynamics of biting midges (as pathogen transmitters) and distribution of these viruses seems to be a result of a complex multifactor process, therefore, it is difficult to predict it on the time and regional scale. The vector transmission of bluetongue and Shmallenberg disease pathogens determines the seasonality of the infections. The increased activity of pathogen transmitters due to population growth and habitat expansion is noted in years with favorable weather conditions (humidity, temperature, insolation).

Global climate changes on the planet have created the conditions for distribution of a wide range of infectious diseases in the regions previously considered as problem-free in this regard. In this situation, bringing of transmissible infections into livestock farms may be associated with very big economic losses, and new transmission mechanisms significantly increase the risks of distribution. Thus, bluetongue has always been considered to be a transmissible disease (Office International des Epizootics, OIE, France, 2011), but it turned out that bluetongue virus of serotype 26, for example, can be transmitted by way of contacts [67], and molecular biologic mechanisms of this phenomenon are understudied yet.

Another important point in the epizootiology of arbovirus infections is still the overwintering of bluetongue virus. The most evident and proved factor of bluetongue virus transmission is a warm climate which is optimal for year-round development and breeding of transmitters. This is very typical for Africa, Southern Europe and Southeast Asia.

It is suggested that another possible mechanism of bluetongue virus overwintering may be associated with persistent infection of T-cells in ruminants 
without immune reaction induction [68], however, this fact has not been confirmed for cattle in field conditions [69]. Transplacental transmission is possible for the animals infected with BTV-8 [70], but the detailed study of this phenomenon on naturally contaminated sheep showed that this mechanism plays an insignificant role in virus overwintering [71, 72]. Such transmission was previously typical only for vaccine live viruses [73]. The possibility of contact virus transmission by alimentary or aerogenic way has also been demonstrated by now, but only on goats [67]. There is a hypothesis about transovarial transmission in biting midges, which is based on the identification of virus RNA in the fertilized eggs of transmitters [74], however, in spite of numerous studies, live virus has not been found yet [56].

So, taking into account the weather conditions influencing the mass character, activity and species diversity of basic biting midge species of the genus Culicoides, these insects may play an important role in the distribution of arbovirus infections, including bluetongue virus (and, presumably, Shmallenberg disease), over the territory of the Russian Federation. Biting midges are spread throughout the territory of Russia, and their northernmost habitat includes the Republics of Karelia, Komi and Sakha, as well as Magadan and Chukotka. It is important to note that the northernmost species is $C$. pulicaris (both in Magadan and the Komi Republic). C. pulicaris predominance over all the other species is typical for areas with harsh climate. In addition, numerous water bodies, pools, swamped areas, as well as damp forest litter with decaying plant residues, favor the development of these insects. At the same time, the geographic location of basic animal habitats and management areas in the Russian Federation is beyond the traditional range of bluetongue virus, and, due to winters with negative temperatures, prolonged non-flight period, and autumn and spring frosts, biting midges cannot emerge until stable optimal temperature $\left(7-21^{\circ} \mathrm{C}\right)$ is established, which ultimately can substantially limit the transmission of infectious agents and, therefore, reduce the possibility of their anchoring in the territory of Russia. However, global climatic changes in recent years cast doubt on the established beliefs regarding the habitat of bluetongue virus, and new data on potential transmission ways become available. In addition, climatic changes affect the development, distribution and activity of vector insects, which points out the necessity of updating the data on the condition of their populations.

\section{REFEREN CES}

1. Gluk hova V.M. Seriya Fauna SSSR. Nasekomye dvukrylye [Ser. Fauna of the USSR. Dipterides. V. 3. Issue 5a]. Leningrad, 1989, tom 3, vypusk 5a.

2. M i rza e va A.G. Krovososushchie mokretsy (Diptera, Ceratopodonidae) Sibiri i Dal'nego Vostoka [Blood sucking Diptera:Ceratopodonidae in Siberia and the Far East]. Novosibirsk, 1989.

3. Mitrofanova Yu.G., Burylova A.M. V sbornike: Itogi issledovaniya po probleme bor'by s gnusom [In: The mosquito investigations and control]. Novosibirsk, 1967: 141-147.

4. Go rn o st a e v a R.M. Parazitologiya, 1978, 12(4): 297-305.

5. S a v chuk T.E. Krovososushchie mokretsy yuzhnoi sel'skokhozyaistvennoi zony Tyumenskoi oblasti (bioekologicheskie osnovy zashchity krupnogo rogatogo skota). Avtoreferat kandidatskoi dissertatsii [Blood-sucking midges in the southern rural zone of Tyumen' Province: bioeclogical bases for cattle protection. PhD Thesis]. Tyumen', 2004.

6. M i r z a v a A.G. Parazitologiya, 1969, 3(4): 320-328.

7. Mirzaeva A.G., Polyakova P.E., Bobrova S.I., Go moyunova I.P. Parazitologiya, 1973, 7(2): 97-105.

8. M e z e n e v N.P. Parazitologiya, 1968, 2(6): 568-571.

9. K u d ry a v s e v a G.A. Uchenye zapiski Yskutskogo universiteta, 1960, 18: 109-115.

10. Y a k u b V.N. V sbornike: Problemy parazitologii [In: Problems of parasitology]. Kiev, 1963: 431-437.

11. M i r z a v a A.G. V sbornike: Ekologiya i geografiya chlenistonogikh Sibiri [In: Ecological and 
geographical characteristics of arthropoda in Siberia]. Novosibirsk, 1987: 243-245.

12. O st ro u s h k o T.S. Parazitologiya, 1969, 3(5): 468-471.

13. Glukhova V.M. Fauna $i$ ekologiya mokretsov (Culicoides) Karelo-Finskoi ASSR. Kandidatskaya dissertatsiya [Fauna and ecological characteristics of Culicoides midges in Karelo-Finnish ASSR. PhD Thesis]. Leningrad, 1956.

14. G 1 u k h o v a V.M. Trudy Zoologicheskogo instituta AN SSSR (Leningrad), 1962, 31: 197-249.

15. A mosova I.S. Fauna $i$ biologiya mokretsov roda Culicoides (sem. Heleidae) khvoinoshirokolistvennykh lesov yuga Primorskogo kraya [Fauna and biology of Culicoides (Heleidae) midges from coniferous deciduous forests in the South of Primorskii Region]. Leningrad, 1956.

16. Gutsevich A.V. Seriya Fauna SSSR. Nasekomye dvukrylye [Ser. Fauna of the USSR. Dipterides. V. 3. Issue 5]. Leningrad, 1973, tom 3, vypusk 5.

17. D e g t y a r e va K.T. Fauna i ekologiya mokretsov roda Culicoides v usloviyakh Voronezhskoi oblasti. Avtoreferat kandidatskoi dissertatsii [Fauna and ecology of Culicoides midges in the Voronezh Province. PhD Thesis]. Voronezh, 1964.

18. R e m m X.Ya. Fauna krovososushchikh dvukrylykh Estonskoi SSR. Avtoreferat kandidatskoi dissertatsii [Fauna of blood sucking dipterides in Estonian SSR. PhD Thesis]. Tartu, 1955: 1-15.

19. R e m m X.Ya. Entomologicheskoe obozrenie, 1956, XXV(1): 172-183.

20. Shtakel'berg A.A. Trudy Zoologicheskogo instituta AN SSSR (Leningrad), 1954, 15: 199-228.

21. B rod sk a y N.K. Parazitologiya, 1992, 26(3): 257-259.

22. B rodsk y a N.K. Materialy XII s"ezda Russkogo entomologicheskogo obshchestva (19-24 avgusta 2002 goda, Sankt-Peterburg) [Proc. XII Congr. of the Russian Entomological Society, August 19-24, 2002]. St. Petersburg, 2002: 49.

23. Krivosheina N.P. Fauna i biologiya mokretsov (Heleidae) Okskoi poimy. Avtoreferat kandidatskoi dissertatsii [Fauna and biology of Heleidae midges from the Oka floodplain. PhD Thesis]. Moscow, 1956.

24. K ri vo s h e i n a N.P. Entomologicheskoe obozrenie, 1957, XXXVI(2): 418-436.

25. Trukh an M.N. V sbornike: Parazity zhivotnykh i rastenii Belorusskogo Poles'ya [In: Plant and animal parasites in Belarusian Woodland]. Minsk, 1972: 194-242.

26. Delecolle J.-C., Brummer-Korvenkontio M., Kremer M. Culicoides (Diptera, Ceratopogonidae) new to the Finnish fauna light trapped in the Tvarminne area (Hanko, Southern Finland). Notulae Ent., 1983, 63: 88-89.

27. Is a e v V.A. V sbornike: Dvukrylye - perenoschiki zaraznykh zabolevanii [In: Dipterides as vectors for infectious diseases]. Ivanovo, 1970: 30-49.

28. Is a e v V.A. Diapauza $i$ drugie voprosy ekologii krovososushchikh mokretsov Ivanovskoi oblasti. Kandidatskaya dissertatsiya [Diapause and ecology of blood sucking midges from Ivanovo Province. PhD Thesis]. Ivanovo, 1975.

29. I s a e v V.A. Ekologo-fiziologicheskie adaptatsii mokretsov [Ecophysiological adaptation in midges]. Ivanovo, 1997.

30. I s a e v V.A. Estestvennye, obshchestvennye nauki, 2011, 2: 5-9.

31. M o l e v E.V. Zoologicheskii zhurnal, 1958, 37(6): 945-946.

32. N e f e d o v V.V. Zoologicheskii zhurnal, 1962, 41(6): 946-948.

33. I s a e v V.A. Vestnik Ivanovskogo gosudarstvennogo universiteta. Seriya Biologiya. Khimiya. Fizika. Matematika, 2011, 2: 5-9.

34. I s a e v V.A. Vestnik Ivanovskogo gosudarstvennogo universiteta, 2013, 2: 14-21.

35. Dipeolu O.O., Odunrinade A.F. Species of Culicoides breeding on rocks and riverbanks in Nigeria. Ecol. Entom., 1976, 1: 267-274.

36. B raverman Y., Galu n R., Ziv M. Breeding sites of some Culicoides species (Diptera, Ceratopogonidae) in Israel. Mosquito News, 1974, 34(3): 303-308.

37. Me iswinkel R., Nevill E.M., Ve nt e r G.J. Vectors: Culicoides spp. In: Infectious disease of livestock. Cape Town, Oxford, NY, Oxford University Press, 1994, V. 1: 5-89.

38. N i n i o C., A u g o t D., D u f o u r B., D e p a qu it J. Emergence of Culicoides obsoletus from indoor and outdoor breeding sites. Vet. Parasitol., 2011, 183(1-2): 125-129 (doi: 10.1016/j.vetpar.2011.07.020).

39. F rid o li n V.Yu. Trudy Kol'skoi bazy AN SSSR, 1936, 3: 1-295.

40. Mole v E.V. Ekologiya mokretsov (Culicoides) i ikh rol' kak promezhutochnykh khozyaev nematody Onchocerca cervicalis $i$ kak perenoschikov onkhotserkoza loshadei $v$ usloviyakh Moskovskoi i Ivanovskoi oblastei. Kandidatskaya dissertatsiya [Ecology of Culicoides midges and their role as an intermediate host of Onchocerca cervicalis and the vector of horse onchocerciasis in Moscow and Ivanovo provinces. PhD Thesis]. Leningrad, 1955.

41. I s m a i lo v Sh.I. Meditsinskaya parazitologiya, 1969, 6: 724-728.

42. Volik G.N. Izuchenie gnusa i mery bor'by s nim na Kizlyarskikh pastbishchakh Dagestana. Avtoreferat kandidatskoi dissertatsii [Mosquito investigations and protective measures in the Kizlayr pastures of Dagestan. PhD Thesis]. Moscow, 1966.

43. M i r z a e v a A.G. Entomologicheskoe obozrenie, 1984, 63(2): 365-378. 
44. Rasnits y n S.P., K o s o vs kik h V.P. Meditsinskaya parazitologiya, 1979, 48(1): 18-24.

45. Monchadski i A.S., Radzivilovskay a Z.A. Tezisy dokladov I Soveshchaniya po parazitologicheskim problemam [Proc. I Meeting on Parasitology]. Moscow-Leningrad, 1939: 49-50.

46. Arbovirus Surveillance Programme (http://www.biosecurity.govt.nz/).

47. Purse B.V., Mellor P.S., Rogers D.J., S a muel A.R., Mertens P.P., B a ylis M. Climate change and the recent emergence of bluetongue in Europe. Nat. Rev. Microbiol., 2005, 3(2): 171-181 (doi: 10.1038/nrmicro1090).

48. Elbers A.R., Meiswinkel R., Van Weezep E., Van OldruitenborghO o s t e rb a a M.M., K o o i E.A. Schmallenberg virus in Culicoides spp. biting midges, the Netherlands, 2011. Emerg. Infect. Dis., 2013, 19(1): 106-109 (doi: 10.3201/eid1901.121054).

49. Elbers A.R., Meiswinkel R., Van We ezep E., Kooi E.A., Van der Poe 1 W.H. Schmallenberg virus in Culicoides biting midges in the Netherlands in 2012. Transbound Emerg. Dis., 2013, Jul 24 (doi: 10.1111/tbed.12128).

50. De Regge N., Madder M., Deblauwe I., Losson B., Fassotte C., Demeule meester J., S meets F., Tomme M., Cay A. Schmallenberg virus circulation in Culicoides in Belgium in 2012: field validation of a real time RT-PCR approach to assess virus replication and dissemination in midges. PLoS ONE, 2014 Jan 23, 9(1): e87005 (doi: 10.1371/journal.pone.0087005).

51. B e lo k u r V.M. Entomologicheskoe obozrenie, 1960, 39(2): 404-409.

52. $\mathrm{Mu}$ ijs k e $\mathrm{ns}$ Ing.J. The overwintering behavior of adult Culicoides species on livestock farms in the Netherlands and the effect of indoor insecticidal treatment on Culicoides species density. $P h D$ Thesis. Wageningen University, 2008.

53. Viennet E., Garros C., Rakoto arivony I., Allène X., Gardès L., Lhoir J., Fuentes I., Venail R., Crochet D., Lancelot R., Riou M., Moulia C., B a ld et T., B a le nghi e n T. Host-seeking activity of bluetongue virus vectors: endo/exophagy and circadian rhythm of Culicoides in Western Europe. PLOS ONE, 2012, 7(10): e48120 (doi: 10.1371/journal.pone.0048120).

54. Wilson A.J., Mellor P.S. Bluetongue in Europe: past, present and future. Philosophical Transactions of the Royal Society B: Biological Sciences, 2009, 364: 26692681 (doi: 10.1098/rstb.2009.0091).

55. Mellor P.S. The replication of bluetongue virus in Culicoides vectors. Curr. Top. Microbiol. Immunol., 1990, 162: 143-161.

56. Mellor P.S., B o o r m a n J., B a y lis M. Culicoides biting midges: their role as arbovirus vectors. Annu. Rev. Entomol., 2000, 45: 307-340 (doi: 10.1146/annurev.ento.45.1.307).

57. Darpel K.E., Langner K.F., Nimtz M., Anthony S.J., Brownlie J., Takamatsu H.H., Mellor P.S., Mertens P.P. Saliva proteins of vector Culicoides modify structure and infectivity of bluetongue virus particles. PLOS ONE, 2011, 6(3): e17545 (doi: 10.1371/journal.pone.0017545).

58. Carpenter S., Lunt H.L., Arav D., Venter G.J., Mel1or P.S. Oral susceptibility to bluetongue virus of Culicoides (Diptera:Ceratopogonidae) from the United Kingdom. J. Med. Entomol., 2006, 43(1): 73-78 (doi: 10.1603/0022-2585(2006)043[0073:OSTBVO]2.0.CO;2).

59. Mellor P.S., Rawlings P., B a ylis M., Wellby M. Effect of temperature on African horse sickness virus infection in Culicoides. Arch. Virol., 1998, 14(Suppl.): 155-163 (doi: 10.1007/978-3-7091-6823-3 15).

60. Wittmann E.J., Mel1 or P.S., B a y 1 is M. Effect of temperature on the transmission of orbiviruses by the biting midge, Culicoides sonorensis. Med. Vet. Entomol., 2002, 16: 147-156 (doi: 10.1046/j.1365-2915.2002.00357).

61. Doherty R.L., Carley J.G., S tandfast H.A., D y ce A.L., S nowdon W.A. Virus strains isolated from arthropods during an epizootic of bovine ephemeral fever in Queensland. Aust. Vet. J., 1972, 48: 81-86.

62. St George T.D., Standfast H.A., Cybinski D.H. Isolation of Akabane virus from sentinel cattle and Culicoides brevitarsis. Aust. Vet. J., 1978, 54: 558-561.

63. St George T.D., Standfast H.A. Simbu group viruses with teratogenic potential. In: The arboviruses: epidemiology and ecology. T.P. Monath (ed.). Boca Raton (FL), CRC Press, 1989, V. 4.

64. De Regge N., Madder M., Deblauwe I., Losson B., Fassotte C., De meulemeester J., S meets F., To m m e M., C a y A.B. Schmallenberg virus sirculation in Culicoides in Belgium in 2012: Field validation of a real time RT-PCR approach to assess virus replication and dissemination in midges. PLoS ONE, 2014, 9(1): e87005 (doi: 10.1371/journal.pone.0087005).

65. Hoffmann B., Scheuch M., Hoper D., Jungblut R., Holsteg M., Schirrmeier H., Eschbaumer M., Goller K.V., Wernike K., Fischer M., B reithaupt A., Mettenleiter T.C., Beer M. Novel orthobunyavirus in sattle, Europe, 2011. Emerg. Infect. Dis., 2012, 18(3): 469-472 (doi: 10.3201/eid1803.111905). 
66. Mac Lachlan J., Guthrie A. Re-emergence of bluetongue, African horse sickness, and other Orbivirus diseases. Vet Res., 2010, 41(6): 35 (doi: 10.1051/vetres/2010007).

67. B at t e n C.A., He n s t o ck M.R., S te e d man H.M., Wadd ingt on S., Edwards L., O u r a C.A. Bluetongue virus serotype 26: infection kinetics, pathogenesis and possible contact transmission in goats. Vet. Microbiol., 2013, 162(1): 62-67 (doi: 10.1016/j.vetmic.2012.08.014).

68. Takamatsu H., Me 11 or P.S., Mertens P.P., Kirkham P.A., Burroughs J.N., Parkhouse R.M. A possible overwintering mechanism for bluetongue virus in the absence of the insect vector. J. Gen. Virol., 2003, 84: 227-235 (doi: 10.1099/vir.0.18705-0).

69. White D.M., Mecham J.O. Lack of detectable bluetongue virus in skin of seropositive cattle: implications for vertebrate overwintering of bluetongue virus. Vet. Ital., 2004, 40: 513-519.

70. Darpel K.E., Batten C.A., Veronesi E., Williamson S., Anderson P., De nnis on M., Clifford S., S mith C., Philips L., Bidewell C., B a chanekBankowska K., Sanders A., Bin-Tarif A., Wilson A.J., Gubbins S., Merte ns P., Oura C.A., Mellor P.S. Transplacental transmission of bluetongue virus 8 in cattle, UK. Emerg. Infect. Dis., 2009, 15: 2025-2028 (doi: 10.3201/eid1512.090788).

71. Menzies F.D., McCullough S.J., McKeown I.M., Forster J.L., Jess S., Batten C., Murchie A.K., Gloster J., Fallows J.G., Pelgrim W., Mel1 o r P.S., O u r a C.A. Evidence for transplacental and contact transmission of bluetongue virus in cattle. Vet. Res., 2008, 163: 203-209 (doi: 10.1136/vr.163.7.203).

72. De Clercq K., De Leeuw I., Verheyden B., Vandemeulebroucke E., Vanbinst T., Herr C., Meroc E., Bertels G., Steurbaut N., Miry C., De Bleecker K., Maquet G., Bughin J., Saulmont M., Lebrun M., Sustronck B., De Deken R., Hooyberghs J., Houdart P., Raemaekers M., Mintiens K., Kerkhofs P., Goris N., Vandenbussche F. Transplacental infection and apparently immunotolerance induced by a wild-type bluetongue virus serotype 8 natural infection. Transbound Emerg Dis., 2008, 55: 352-359 (doi: $10.1111 / \mathrm{j}$.1865-1682.2008.01044.x).

73. Backx A., Heutink R., Van Rooij E., Van Rijn P. Transplacental and oral transmission of wild-type bluetongue virus serotype 8 in cattle after experimental infection. Vet. Microbiol., 2009, 138: 235-243 (doi: 10.1016/j.vetmic.2009.04.003).

74. White D.M., Wils o n W.C., B lair C.D., B e at y B.J. Studies on overwintering of bluetongue viruses in insects. J. Gen. Virol., 2005, 6: 453-462 (doi: 10.1099/vir.0.80290-0). 